Forests and Governance Programme

\title{
Partisipasi Masyarakat dalam Pembuatan Kebijakan Daerah di Kabupaten Tanjung Jabung Barat, Jambi: Ketidakpastian, Tantangan, dan Harapan
}

Oleh Sudirman, Dede Wiliam dan Siân McGrath

\section{Pendahuluan}

Proses desentralisasi yang diawali sejak tahun 1999 telah memotivasi daerah untuk meningkatkan kemampuan dan kemandirian mereka. Pemerintah kabupaten sekarang mempunyai kesempatan untuk mengelola sumber daya alam mereka sendiri, mengurangi ketergantungan kepada pemerintah pusat dan mempunyai potensi menjadi semakin efisien. Pemerintah daerah mempunyai keleluasaan untuk memerankan tanggung jawabnya seperti yang terlihat dalam banyaknya peraturan daerah yang dihasilkan, termasuk diantaranya sektor kehutanan. Namun demikian, desentralisasi yang juga diharapkan dapat lebih mendekatkan masyarakat lokal kepada proses pembuatan keputusan, sampai saat ini belum memberikan pengaruh yang nyata akan adanya perubahan besar dalam pembuatan kebijakan partisipatif. Selain itu, adanya perbedaan kepentingan antara pengambil keputusan di daerah dan nasional menimbulkan berbagai masalah dalam pelaksanaan kebijakankebijakan yang telah disusun tersebut di lapangan.

Sebagai tindak lanjut dari keluarnya kebijakan pusat tentang Pengusahaan Hutan dan Pemungutan Hasil Hutan pada Hutan Produksi yaitu PP No. 6/1999, Pemerintah Kabupaten Tanjung Jabung Barat (Tanjabbar) mengeluarkan tiga peraturan daerah (Perda) di bidang kehutanan. Yang pertama adalah Perda No. 13/2002, dikenal oleh masyarakat lokal sebagai Ijin Pemungutan Hasil Hutan (IPHH). Perda ini mengatur pelaksanaan empat perijinan IPHH untuk pemungutan hasil hutan kayu dan bukan kayu di Tanjabbar (Gambar 1).

Gambar 1. Perijinan untuk pemungutan hasil hutan di kabupaten Tanjabbar

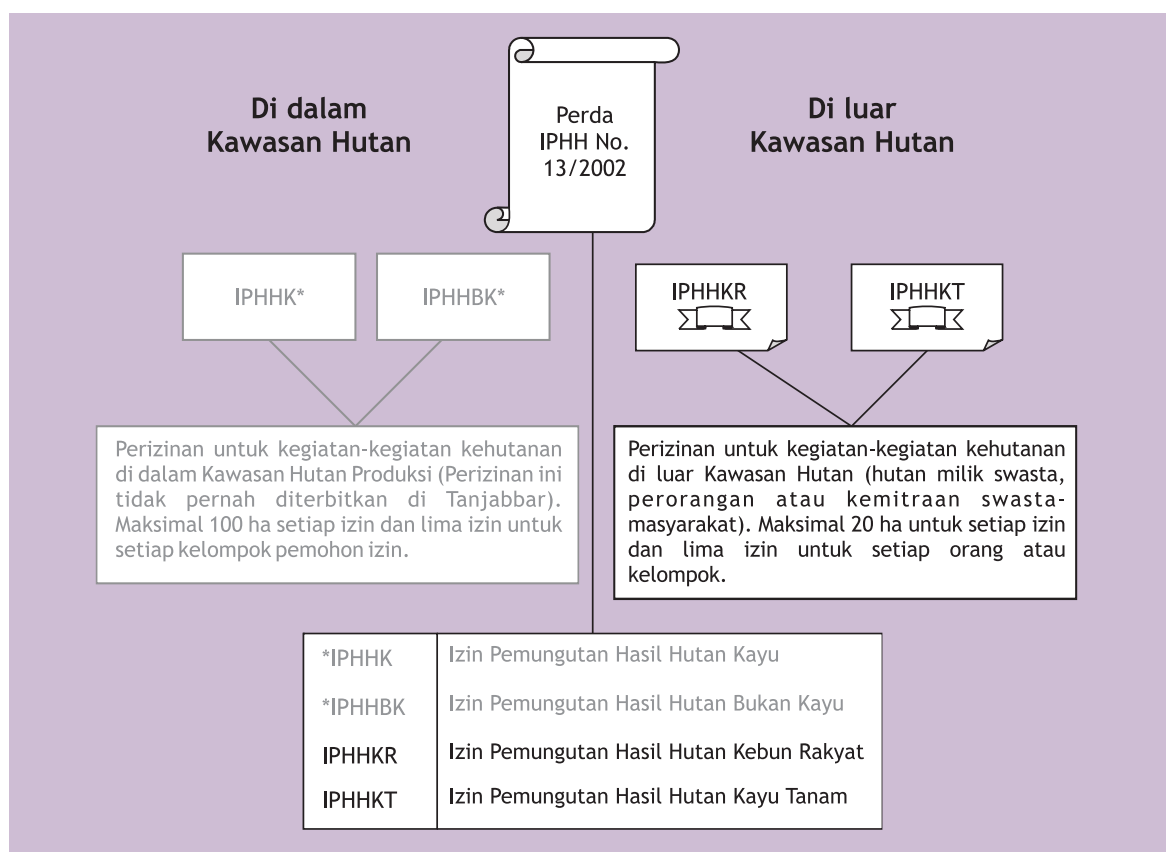


Pemerintah Tanjabbar juga merancang dua Perda lain ${ }^{1}$ yang mengatur penarikan pajak dan penetapan retribusi. Walaupun Perda merupakan alat hukum dan peraturan tertinggi di kabupaten, tak satupun dari Perda di Tanjabbar tersebut yang dapat dilaksanakan tanpa adanya Surat Keputusan ${ }^{2}$ Bupati sebagai peraturan pelaksanaannya.

\section{Ijin Pemanfaatan Hutan di Kabupaten Tanjung Jabung Barat}

Di Tanjabbar, wilayah hutan telah berkurang hampir $40 \%$ dalam dua puluh tahun terakhir. Sejumlah besar hutan dialihfungsikan untuk lahan transmigrasi dan perkebunan kelapa sawit. Terlepas dari menurunnya luasan dan kualitas hutan yang ada, pada tahun 2002 lebih dari setengah wilayah Kabupaten Tanjabbar masih secara resmi (di atas kertas) digolongkan sebagai kawasan hutan negara, yang $87 \%$ diantaranya tergolong sebagai Hutan Produksi.

Kebijakan nasional mengenai HPHH 100 ha $^{3}$ pada dasarnya hanya diperuntukkan untuk wilayah hutan yang tergolong sebagai Hutan Konversi atau Hutan Produksi yang akan dikonversi (dalam kawasan budidaya menurut padu serasi). Sementara itu, kawasan hutan yang ada di Tanjabbar saat ini hampir sudah tidak ada yang termasuk pada kedua kategori tersebut. Menyadari hal itu, Pemerintah Tanjabbar pada akhirnya hanya mengeluarkan dua perijinan yang mengatur pemungutan kayu di luar kawasan hutan negara, yaitu ljin Pemungutan Hasil Hutan Kayu Rakyat (IPHHKR) dan Ijin Pemungutan Hasil Hutan Kayu Tanam (IPHHKT). Kedua ijin ini hanya berlaku atas wilayah berhutan di: lahan perdesaan, wilayah adat, dan wilayah yang dimiliki oleh perorangan, perusahaan atau lahan yang dikelola bersama dengan pola kemitraan antara perusahaan swasta dengan masyarakat setempat.

Sedangkan dua perijinan lainnya yang diatur oleh Perda IPHH, yaitu Ijin Pemungutan Hasil Hutan Kayu (IPHHK) dan Ijin Pemungutan Hasil Hutan Bukan Kayu (IPHHBK), hanya dapat digunakan di dalam kawasan Hutan Produksi (hutan negara). Kabupaten Tanjabbar tidak pernah mengeluarkan kedua perijinan ini. Oleh karena itu, ketika pemerintah pusat mencabut hak Bupati untuk menerbitkan ijin pemungutan kayu di hutan produksi ${ }^{4}$, hal tersebut tidak banyak berpengaruh pada kebijakan kehutanan yang ada ataupun pelaksanaannya di Tanjabbar. Bupati Tanjabbar masih terus menerbitkan perijinan pemanfaatan kayu di luar kawasan hutan yang memang sejak semula berada di luar kewenangan pemerintah pusat.

Untuk mengantisipasi kemungkinan munculnya dampak negatif dari Perda IPHH tersebut, Bupati mengeluarkan Surat Keputusan yang mengatur proses permohonan ijin HPHH dan pelaksanaan rotasi penebangannya. Perda No. 13 ini secara ringkas juga menjelaskan kegiatan penebangan, pengelolaan dan dampak-dampaknya, serta kewajiban pemilik hak untuk merehabilitasi lahan bekas tebangan. Sayangnya, peraturan tersebut tidak menjelaskan lebih lanjut bagaimana atau kapan kegiatan-kegiatan tersebut harus dilakukan dan bagaimana mekanisme pengawasannya. Pemohon yang memperoleh ijin IPHH hanya mempunyai batas waktu enam bulan untuk melaksanakan semua kegiatan dan dapat memohon perpanjangan "hanya jika jumlah produksi kayu yang tersedia masih memungkinkan" ${ }^{5}$. Hal ini berarti bahwa perpanjangan ijin tidak dapat diberikan apabila tidak ada lagi kayu yang dapat ditebangyang secara otomatis menghapuskan kemungkinan untuk melaksanakan kegiatan rehabilitasi lahan pasca penebangan.

Kebijakan IPHH ini juga memperbesar kemungkinan pemohon ijin memanfaatkan pohon-pohon yang masih tersisa di daerah-daerah hutan alam di luar kawasan hutan. Dalam waktu singkat bukan tidak mungkin seluruh wilayah hutan alami di Tanjabbar, selain kawasan hutan Taman Nasional Bukit Tiga Puluh (9.105 ha) dan wilayah hutan yang bersebelahan yang sebelumnya adalah milik PT Hatma Shanti ${ }^{6}$, akan habis.

\section{Rekomendasi untuk Mereformasi Peraturan-peraturan Kehutanan}

\section{Tanjabbar}

Berdasarkan hasil tinjauan atas tiga peraturan kehutanan Tanjabbar tersebut di atas, reformasi kebijakan dapat diarahkan pada setidaknya tiga isu mendasar, yaitu:

1. Pembuatan Rancangan Kebijakan Kabupaten:

Perda yang dibuat seharusnya sejalan dengan undang-undang desentralisasi dan undang-undang kehutanan nasional yang berlaku7 . Sementara ini, Perda kehutanan Tanjabbar masih mengacu pada undang-undang lama. Hal ini menyebabkan adanya beberapa Pasal dalam Perda yang bertentangan dengan peraturan yang lebih tinggi. Masyarakat juga belum dilibatkan secara aktif dalam proses pembuatan kebijakan. Hal ini tidak sejalan dengan amanat Pasal 68 UU Kehutanan No. 41/1999, dan Pasal 4 (5) UU No. 34/2000 mengenai Pajak dan Retribusi Daerah.

2. Peraturan Pelaksanaan dan Fungsi Pengawasan yang tidak jelas

Ketentuan pelaksanaan yang tidak jelas dan fungsi pengawasan yang lemah menjadi kendala dalam penerapan Perda kehutanan di Tanjabbar. Contohnya, Pasal 14 (3) Perda IPHH menyatakan bahwa ijin pemanfaatan hasil hutan dapat dicabut bila suatu saat pemiliknya melanggar ketentuan peraturan perundang-undangan yang berlaku. Tidak jelas disebutkan pelanggaran seperti apa dan terhadap peraturan yang mana atau undang-undang nomor berapa, pemilik ijin $\mathrm{IPHH}$ dapat dicabut hak-haknya. Kenyataan ini sangat membingungkan baik bagi pemegang ijin dan pejabat yang berwenang. 


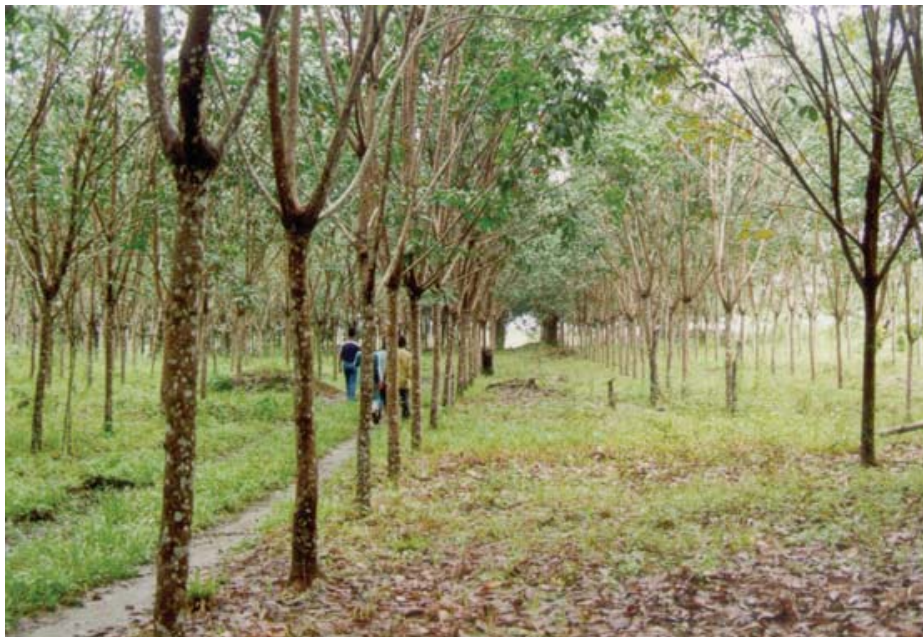

Pemilik perkebunan karet tradisional, Jambi. (Foto oleh Toni Djogo)

3. Permasalahan Teknis di Lapangan

'Pungutan ganda', yaitu pungutan pajak dan retribusi yang sama oleh pemerintah pusat dan daerah. Pasal 3 (2 dan 3) Perda No.15/2002 tentang RHH mewajibkan pemilik ijin untuk membayar PSDH, DR dan RHH untuk pemanfaatan hasil hutan. Perda ini juga mewajibkan pemegang ijin membayar Provisi Sumber Daya Hutan (PSDH), Dana Reboisasi (DR) dan Retribusi Hasil Hutan $(\mathrm{RHH})$. Sementara itu, untuk ijin yang sama, pemerintah pusat juga mensyaratkan pemilik ijin untuk membayar PSDH dan DR. Dengan demikian, ketentuan dalam Perda $\mathrm{RHH}$ ini tidak sejalan dengan kebijakan nasional yang menyebutkan bahwa PSDH dan DR merupakan penerimaan negara bukan pajak, yang harus disetorkan kepada pemerintah pusat sebagaimana diatur antara lain dalam PP 20/1997.

Kewenangan kabupaten untuk memungut pajak retribusi kehutanan ini juga memungkinkan mereka untuk mengenakan pajak serupa atas kayu-kayu ilegal. Hal ini menjadi dilema bagi pejabat kehutanan kabupaten. Di satu sisi, tanpa pengenaan pajak dapat dipastikan bahwa kayukayu tersebut akan keluar dari wilayah Tanjabbar tanpa sumbangan apapun bagi kas daerah. Di sisi lain, dengan memberlakukan pungutan pajak terhadap kayu ilegal, secara efektif dapat dianggap melegalkan kayu-kayu hasil pembalakan liar.

\section{Proses Pembuatan Peraturan Daerah di Tanjabbar}

Sebagaimana kebanyakan daerah lainnya di Propinsi Jambi, kebijakan di tingkat eksekutif Tanjabbar masih diatur dalam keputusan kepala daerah (Bupati), yang mekanismenya mengacu pada UU No. 5/1974 dan peraturan pelaksanaannya dengan penyesuaian parsial, serta mengacu pada keputusan kepala daerah yang dikeluarkan antara tahun 1992 dan $1993^{\circ}$. Terdapat dua mekanisme, yaitu: Pertama, anggota dewan mengajukan rancangan peraturan, yang kemudian diperdebatkan di sidang dewan. Metode ini hanya mungkin dilaksanakan apabila anggota-anggota dewan mempunyai cukup keahlian dan pengalaman untuk menyusun rancangan peraturan tersebut.

Kedua, lembaga eksekutif mengawali proses perancangan Perda, yang kemudian menyerahkan hasil rancangan tersebut pada Dewan Perwakilan Rakyat Daerah (DPRD). Semua proses pembuatan Perda di Tanjabbar mengikuti cara yang kedua ini. Alasannya, lembaga eksekutif dianggap lebih memahami isu-isu yang berkembang di sektor masing-masing sehingga lebih bertanggung jawab atas pelaksanaan peraturanperaturan tersebut. Alasan lainnya adalah kapasitas yang ada di dewan tidak memungkinkan untuk menyusun rancangan kebijakan daerah.

Proses pembuatan kebijakannya itu sendiri melalui empat tahap:

1. Perancangan Kebijakan: lembaga eksekutif menyusun rancangan kebijakan. Misalnya, Dinas Kehutanan membuat rancangan peraturan daerah yang mencakup masalah pengelolaan hutan.

2. Penyelarasan Rancangan Kebijakan di Bagian Hukum Sekretariat Daerah (Setda) Pemda Tanjabbar: Pada tahap ini Dinas Kehutanan membahas rancangan tersebut bersama dengan Bagian Hukum Sekretariat Daerah. Pembahasan menyangkut penulisan dan kaidah-kaidah norma hukum dalam rancangan Perda.

3. Pra-persidangan: Panitia Musyawarah (Panmus) DPRD menetapkan jadwal pembahasan Rancangan Perda (Raperda).

4. Persidangan Dewan: meliputi Rapat Paripurna I, II, III, IV dan V yang membahas antara lain:

- Paripurna I adalah penyampaian Nota Pengantar Bupati atas rancangan yang diajukan ke Dewan.

- Paripurna II: penyampaian Pandangan Umum Fraksi DPRD.

- Paripurna III: penyampaian tanggapan eksekutif terhadap Pandangan Umum Fraksi

- Paripurna IV: biasa disebut Rapat Kerja Panitia Khusus (Pansus) dengan instansi teknis terkait dan dilanjutkan dengan pembacaan laporan Pansus.

- Paripurna V: sebelum penutupan, semua fraksi membacakan ringkasan pandangan akhir fraksi (stemotivering) dan Raperda ditetapkan menjadi Perda. Rapat diakhiri dengan sambutan kepala daerah (Bupati)

Rangkaian proses pembuatan kebijakan daerah seperti yang diuraikan di atas tidak memberikan ruang yang cukup bagi keikutsertaan publik. Selain itu juga, dengan rancangan peraturan yang selalu diprakarsai oleh lembaga eksekutif sangat mempengaruhi keputusan akhir yang cenderung sarat muatan kepentingan sektoral. Hal ini tampak dari isi Perda serta konsistensinya dengan peraturanperaturan dalam sektor lain yang kurang terintegrasi satu sama lain. 


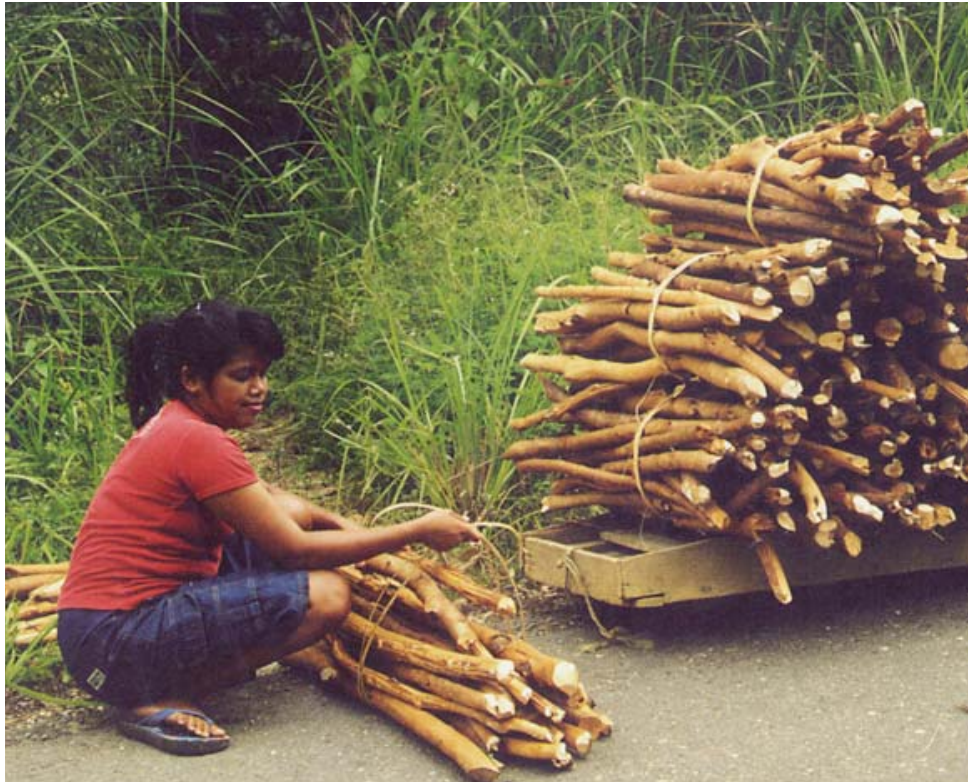

Foto oleh Toni Djogo

Dengan semangat desentralisasi yang saat ini semakin meluas, Kabupaten Tanjabbar sebenarnya juga sangat membutuhkan kebijakan baru yang secara eksplisit mengatur bagaimana partisipasi masyarakat dapat terakomodasi di segala tahapan, dari proses perancangan kebijakan hingga pelaksanaannya. Intinya adalah bagaimana mencari keseimbangan antara mendapatkan sebanyak mungkin masukan dari berbagai pihak (stakeholders) dengan fasilitas dan anggaran yang tersedia. Secara ideal, suatu proses yang lebih komprehensif dapat memberi kesempatan kepada masyarakat untuk mempertimbangkan isu-isu seperti bagaimana penebangan hutan berdampak luas terhadap masalah banjir, kekurangan pasokan kayu bakar bagi masyarakat perdesaan dan kekurangan bahan-bahan bangunan di masa depan, dan juga masalah semakin berkurangnya lahan pertanian bagi petani kecil karena wilayah hutan dialihfungsikan untuk hal lain.

\section{Prinsip-prinsip Hukum Pembuatan Kebijakan Daerah}

Pemahaman mengenai prinsip-prinsip hukum akan menentukan kualitas rancangan hukum dalam kebijakan akhir. Tinjauan hukum atas kebijakankebijakan kehutanan Tanjabbar ${ }^{9}$ menyoroti beberapa prinsip dasar pembuatan kebijakan, sebagai berikut:

1. Peraturan-peraturan daerah seharusnya sejalan dengan peraturan yang lebih tinggi. Peraturan daerah maupun nasional yang dibuat tidak bertentangan dengan peraturan sejenis lainnya atau dengan peraturan perundang-undangan yang lebih tinggi tingkatannya. Suatu Perda yang telah terbentuk dapat dianggap bertentangan dengan peraturan perundang-undangan yang lebih tinggi jika Perda tersebut kewenangannya, dari aspek teknis ataupun materi muatan Perda, tidak konsisten dengan peraturan yang lebih tinggi, atau Perda tersebut mengacu pada peraturan yang sudah tidak berlaku lagi.

2. Peraturan-peraturan nasional perlu ditinjau ulang dan diperbaiki untuk memungkinkan daerah menyusun kebijakan-kebijakan berdasarkan ragam kebutuhan dan aspirasi masyarakat setempat. Seringkali Pemerintah Daerah menerapkan kebijakan-kebijakan yang tidak mencerminkan kenyataan yang ada di daerah hanya karena daerah memandang dirinya harus melayani kepentingan-kepentingan pemerintah pusat (Jakarta). Dengan demikian, proses perancangan hukum di Jakarta juga harus melibatkan daerah terkait untuk menjamin pelaksanaan, kesetaraan dan kesesuaiannya dengan kebutuhan pemangku kepentingan di daerah. Hal ini juga akan memberikan tanggung jawab pada daerah untuk pelaksanaannya.

3. Peraturan nasional maupun daerah seharusnya selaras dengan hukum dan norma adat setempat. Kebijakan nasional dalam era desentralisasi ${ }^{10}$ telah mengisyaratkan adanya pengakuan terhadap hukum lokal (desa atau adat) dan kesatuankesatuan masyarakat hukum adat berikut otonominya yang sempat hilang pada masa Orde Baru ${ }^{11}$.

4. Peraturan-peraturan daerah seharusnya tidak bertentangan dengan asas-asas umum penyelenggaraan tata pemerintahan yang baik (good governance), yaitu:

a. Asas-asas formal dalam proses pengambilan keputusan, meliputi: asas kecermatan formal (kejelasan atas subjek, isi, dan pengertian), asas keseragaman perlakuan (fair play), dan asas larangan penyimpangan secara teknis (detournement de procedure);

b. Asas-asas formulasi keputusan, meliputi: asas pertimbangan, keadilan dan asas kepastian hukum formal

c. Asas-asas material keputusan, meliputi: asas kepercayaan atau harapan yang telah ditimbulkan, asas persamaan, asas kecermatan material, asas keseimbangan, asas penyalahgunaan kekuasaan (detournement de pouvoir), dan asas larangan sewenang-wenang (willekeur)

5. Peraturan-peraturan daerah tidak semestinya memiliki dampak-dampak negatif dalam aspek ekologi, lingkungan atau ekonomi baik bagi daerahnya maupun wilayah tetangganya.

Dimensi-dimensi hukum tersebut di atas perlu dipertimbangkan dalam perumusan kebijakan daerah maupun nasional untuk menghindari pembuatan dan pelaksanaan kebijakan yang cacat hukum. Suatu Peraturan yang cacat hukum mempunyai kecenderungan besar untuk adanya pembatalan, baik melalui pencabutan peraturan tersebut oleh pejabat yang berwenang ataupun melalui mekanisme hak uji materil di Mahkamah Agung (MA). 


\section{Mengapa Partisipasi Masyarakat Dibutuhkan?}

Partisipasi masyarakat dalam pembentukan kebijakan berada pada urutan yang tinggi dalam agenda desentralisasi, seperti diamanatkan oleh UU No. $18 / 1997$ jo UU No. 34/2000, UU No. 22/1999, UU No. $41 / 1999^{12}$ dan UU No. 10/2004. Ini berarti bahwa undang-undang harus menjamin partisipasi masyarakat. Hasil-hasil positif yang diharapkan terjadi antara lain:

1. Peraturan daerah didasarkan terutama pada kepentingan dan kebutuhan masyarakat. Berbagai peraturan akan lebih sesuai dengan kenyataan, dan lebih mungkin memenuhi harapan-harapan masyarakat lokal.

2. Mendorong masyarakat lokal untuk lebih mematuhi peraturan dan bertanggung jawab secara sosial. Masyarakat akan cenderung lebih patuh terhadap peraturan yang pembuatannya melibatkan mereka secara aktif.

3. Memberdayakan pemerintah daerah untuk mendemokratisasi proses pembuatan kebijakan, dan menjadi lebih bertanggung gugat kepada pemilih mereka. Konsultasi terbuka dengan para pemangku kepentingan, seperti universitas, lembaga swadaya masyarakat (LSM), dan masyarakat umum, memungkinkan "pengawasan dan keseimbangan" menjadi bagian dalam proses.

Sebetulnya Propinsi Jambi telah mencoba membangun partisipasi masyarakat dalam proses pembuatan kebijakan melalui Program Pembangunan Daerah (Propeda) ${ }^{13}$. Hal ini merupakan langkah awal yang baik guna lebih mendorong partisipasi yang lebih luas masuk dalam mekanisme pembuatan kebijakan.

\section{Kesimpulan dan Rekomendasi}

Setelah meninjau proses pembuatan kebijakan kehutanan daerah Tanjabbar, kami menyimpulkan:

1. Mekanisme pembuatan kebijakan perlu diperbaiki karena:

a. Masih terdapat kelemahan prosedur dasar.

b. Isi yang tidak jelas dan kebijakan-kebijakan yang tidak aplikatif sehingga sulit untuk dilaksanakan di lapangan.

2. Peraturan daerah baik secara umum, regional, maupun nasional seharusnya berorientasi pada pengelolaan sumberdaya hutan daerah secara berkelanjutan.

3. Partisipasi masyarakat adalah penting untuk menghindari peraturan perundangan yang hanya menguntungkan sebagian orang atau kelompok tertentu. Mekanisme yang jelas dibutuhkan oleh masyarakat lokal untuk menyuarakan pendapat dan aspirasi mereka, dan untuk terlibat aktif dalam pembuatan dan pelaksanaan kebijakan daerah.

Kami merekomendasikan:

1. Pemerintah pusat seharusnya bekerja dengan

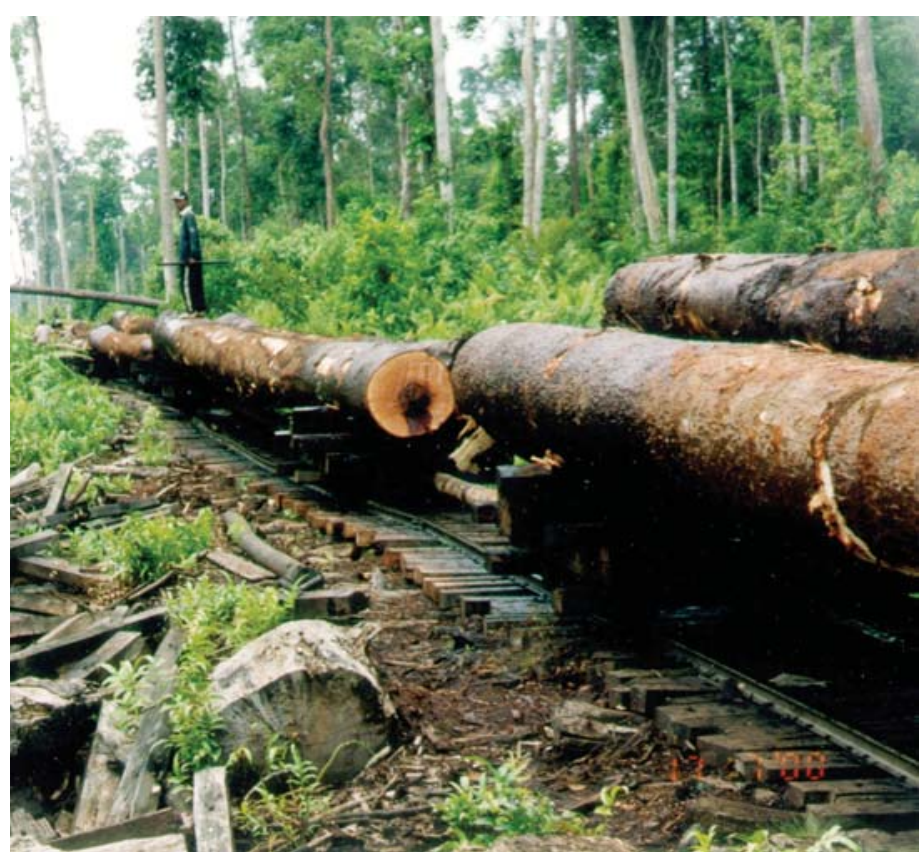

Foto oleh Chandra Budi

pemerintah daerah untuk membentuk suatu kerangka kerja sama bagi penyusunan peraturanperaturan daerah yang mampu memenuhi kebutuhan lokal sejalan dengan standar-standar nasional yang diterima umum.

2. Pemerintah Kabupaten Tanjabbar agar meninjau kembali dan mengevaluasi peraturan-peraturan daerah terkait kehutanan, dengan melibatkan para pemangku kepentingan dari kalangan luas, termasuk masyarakat yang terkena dampak.

3. Partisipasi masyarakat dapat lebih ditingkatkan dengan langkah-langkah sebagai berikut:

1) Menyusun suatu peraturan yang menjamin kesetaraan dan menjamin partisipasi masyarakat. Mekanisme tersebut bisa menjadi acuan bagi pemerintah daerah dalam pembuatan produk hukum dan peraturan daerah agar mematuhi prinsip-prinsip tata pemerintahan. Lebih lanjut, mekanisme partisipatif seperti ini juga akan memperkuat kepercayaan dan kepatuhan masyarakat dalam menjalankan peraturan tersebut.

2) Menyediakan sumberdaya manusia dan dukungan finansial yang memadai. Tidak kalah pentingnya adalah pemerintah daerah memberikan dukungan bagi Dana Partisipasi Masyarakat (DPM) yang dapat dialokasikan dari Anggaran Pendapatan dan Belanja Daerah (APBD), berdasarkan program peraturanperaturan yang direncanakan.

3) Mendorong partisipasi masyarakat dalam pengambilan keputusan, misalnya dalam proses pemberian ijin Hutan Tanaman Industri di lahan sekitar tempat tinggal mereka. Perijinan ini memiliki implikasi serius bagi masa depan hutan-hutan Tanjabbar, sementara saat ini ijin sudah dapat diterbitkan hanya dengan sebuah surat berdasarkan rekomendasi Kepala Dinas kepada Menteri Kehutanan. 
Partisipasi masyarakat dapat dicapai melalui:

a) Rekomendasi-rekomendasi penelitian kebijakan dan naskah akademik;

b) Diskusi terbuka seperti seminar dan lokakarya;

c) Memo kebijakan atau ringkasan kebijakan dikembangkan dengan para pemangku kepentingan lokal dan disebarkan secara luas;

d) Penerbitan kebijakan daerah dalam media cetak dan elektronik;

e) Dengar pendapat di DPRD; dan

f) Penyebaran rancangan peraturan kepada berbagai pemangku kepentingan, untuk meminta masukan sebagai bahan perumusan kebijakan akhir.

\section{Catatan akhir}

1 Perda No. 21/2001 mengenai Ijin Pemungutan Hasil Hutan Ikutan (untuk seterusnya disebut Perda IPHHI); dan Perda No. 15/2002 mengenai Retribusi Hasil Hutan (RHH).

2 Sebagai contoh, Perda IPHH baru dapat dilaksanakan setelah keluarnya Surat Keputusan Bupati No.189/2003 mengenai Pelaksanaan Perda IPHH. SK Bupati ini dianggap sebagai dasar hukum bagi pelaksanaan peraturan-peraturan kehutanan daerah.

3 Pasal 22 ayat 3 PP 6/1999 menyatakan bahwa Hak Pemungutan Hasil Hutan diberikan oleh Bupati,sesuai dengan pedoman yang ditetapkan oleh Menteri Kehutanan. Dalam hal ini, kawasan peruntukan dan pedoman pelaksanaannya diatur oleh Kepmenhut No. 310/1999.

${ }^{4}$ PP No. $34 / 2002$.

${ }^{5}$ Perda No. 13/2002 Pasal 8 (5).

${ }^{6}$ Menurut sumber dari pemerintahan daerah, Departemen Kehutanan akan segera mengeluarkan ijin HTI atas wilayah berhutan yang dulu menjadi hak kelola PT Hatma Shanti.

7 UU No. 22/1999 mengenai Pemerintahan Daerah dan UU No.25/1999 mengenai Perimbangan Keuangan Pusat dan Daerah dan UU No. 41/1999 mengenai Kehutanan. Sejak pertengahan Oktober 2004, UU No. 22/1999 dinyatakan tidak berlaku dengan terbitnya UU 32/2004 dan UU 25/1999 dinyatakan tidak berlaku dengan terbitnya UU 33/2004.
${ }^{8}$ Lihat juga tulisan Fauzi Syam, PSHK-ODA yang berjudul 'Partisipasi publik terhadap kebijakan publik di Propinsi Jambi' (2002); 'Demokratisasi pembuatan peraturan daerah di propinsi Jambi: upaya mewujudkan hukum yang aspiratif dan berwibawa' (2000); 'Increasing public participation in local policymaking' (2000) dan karya-karya tulis terkait lain yang disajikan pada berbagai seminar dan lokakarya di Propinsi Jambi.

9 Yaitu IPHHI, IPHH dan RHH. Lihat juga Kumpulan Modul PSHP UNJA (2000).

${ }^{10}$ UU NO. 22/199 mengisyaratkan adanya pengakuan terhadap keanekaragaman desa (bagian penjelasan Pasal 93 ayat (1) dan ditegaskan kembali dalam aturan pelaksanaannya yaitu PP No. 76 Tahun 2001 tentang Pedoman Umum Pengaturan Mengenai Desa. PP ini juga mengisyaratkan adanya pengakuan kembali terhadap kesatuan-kesatuan masyarakat hukum adat baik yang disebut dengan Nagari, Kampung, Huta, Bori, dan Marga.

${ }^{11}$ Pemerintah Orde Baru mengeluarkan UU No. 5/1979 yang menghilangkan otonomi kesatuan masyarakat hukum adat.

12 UU Kehutanan No. 41/1999 Pasal 68 berjudul "Peran Serta Masyarakat" secara tegas menyatakan bahwa masyarakat memiliki hak untuk menikmati kualitas lingkungan hidup yang dihasilkan hutan. Masyarakat juga memiliki hak atas informasi mengenai rencana peruntukkan hutan dan pemanfaatan hasil hutan, dan sebagainya dengan penekanan pada mekanisme pengikutsertaan mereka dalam proses pembuatan kebijakan. Peraturan lain yang mengatur isu-isu ini adalah Pasal 4 (5) UU No. 34/2000 tentang Pajak dan Retribusi Daerah yang mengisyaratkan bahwa masyarakat berhak memperoleh informasi mengenai perubahan peraturan ataupun pembuatan peraturan baru yang harus terlebih dahulu disosialisasikan pada publik sebelum ditetapkan. Pasal 53 UU No. 10/2004 tentang Pembentukan Peraturan Perundang-undangan berjudul "Partisipasi Masyarakat" menegaskan bahwa masyarakat berhak memberikan masukan secara lisan atau tertulis dalam rangka penyiapan atau pembahasan rancangan undang-undang dan rancangan peraturan daerah.

13 Lihat peraturan daerah mengenai Propeda di Propinsi Jambi bab VII (Perda No. 14A/2001).

Sudirman (PSHK-ODA), Dede Wiliam dan Siân McGrath dari CIFOR mempersiapkan Ringkasan Desentralisasi ini dari laporan: Mekanisme Pengambilan Kebijakan Daerah di Bidang Kehutanan: Proses, Implementasi dan Dampak Desentralisasi pada Sektor Kehutanan di Tanjung Jabung Barat, Jambi. Karya tulis ini didanai oleh ACIAR dan DFID dalam proyek: Dapatkah desentralisasi memberikan manfaat untuk hutan dan masyarakat miskin? Pendapat yang dinyatakan dalam tulisan ini adalah milik penulis pribadi dan tidak selalu mencerminkan pandangan badan penyandang dana.
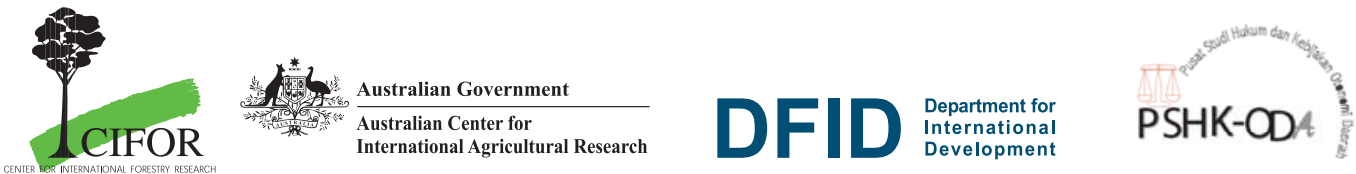

Center for International Forestry Research, CIFOR

Office: Jalan CIFOR, Situ Gede, Sindang Barang, Bogor

Barat 16680, Indonesia. Mailing: P.O. Box. 6596 JKPWB,

E-mail: cifor@cgiar.org Website: www.cifor.cgiar.org

Jakarta 10065, Indonesia

Foto-foto halaman depan oleh: Toni Djogo dan Chandra F U T U R E Budi 